Journal of Engineering and Applied Sciences 15 (6): 1537-1543, 2020

ISSN: 1816-949X

(C) Medwell Journals, 2020

\title{
Flexural Charachteristics of RC Beam with Hollow Core Variation in Tension Area
}

\author{
${ }^{1}$ Syahrul Sariman, ${ }^{2}$ Herman Parung, ${ }^{2}$ Rudy Djamaluddin and ${ }^{2}$ Rita Irmawaty \\ ${ }^{1}$ Department of Civil Engineering, Bosowa University, Makassar, Indonesia \\ ${ }^{2}$ Department of Civil Engineering, Hasanuddin University, Gowa Regency, Indonesia
}

\begin{abstract}
Nowadays, research efforts are continuously conducted to looking for new, better and efficient construction materials and methods. The concrete should be used efficiently because the concrete section under the neutral axis will not be calculated. Therefor in this study, the partial replacement of concrete under the neutral axis by using different variation of plastic bottles is discussed. Six specimens are tested, consisting of one control beam (BN) and three hollow beams with different length (BR3A, BR3B and BR3C) and two hollow beams with different height ( BR1C and BR2C). All beams are tested with four loading points to investigated the flexural characteristics of the beams. The results showed that the flexural capacity of reinforced concrete beam with hollow core (BR3A, BR3B, BR3C and BR1C) was almost same with the normal beam but the BR2C can not reached the flexural capacity because the width of beam too thin. Moreover, the effect of the hollow core was also insignificant on the flexural capacity where the beam with higher and longest hollow core showed similar flexural capacity with the beam having a lower hollow.
\end{abstract}

Key words: Moment capacity, load deflection, hollow RC beam, BR2C, flexural capacity

\section{INTRODUCTION}

Reinforced concrete is the dominant structural material in engineering construction due to its advantages such as workability, low cost and fire resistance as well as low maintenance cost. Unfortunately, the reinforced concrete structure has its own heavy weight, besides in the manufacture of cement which is the base material of making concrete mixture, giving contribution to $\mathrm{CO}_{2}$ emission. Massive exploration of the natural materials for producing concretes affect to the environment condition and global warming that may cause disaster such as flooding and land-slides. Related to that, research efforts are continuously conducted to looking for new, better and efficient construction material and method. The concrete should be used as efficiently as much as possible In Reinforced Concrete (RC) beams, concrete on tension zone has no effect on the flexural action. Figure 1 shown the flexural action of Reinforced concrete beam due to flexure load.

Therefore, the contribution of the tensile stresses of the concrete to the flexural capacity of the beams is neglected, so that, the part can be replaced with weaker material or eliminated. Several study have been conducted on this subject. Varghese and Basil (2016) have studied material incorporated in the concrete beam is expanded polystyrene and polyurethane foam which occupy the concrete volume below the neutral axis. Specimens of solid RC beams and hollow core RC sandwich beams with various core thickness are casted and tested for three

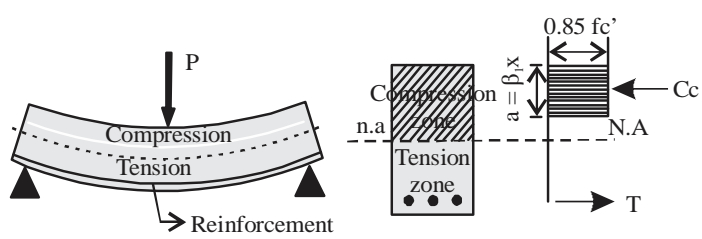

Fig. 1: Flexural action of reinforced concrete beam

point flexure. Hollowcore sand which beams shows similar behaviour in flexure as that of control beam. Irmawaty et al. (2016) to analyze the flexural behavior of Styrofoam-Filled Concrete (SFC) by adding Styrofoam $30 \%$ to replace the concrete volume on tension area. The results indicate that the strength of Normal Concrete (NC) and SFC has decreased with addition of 30\% Styrofoam. However, when the SFC beam was combined with deformed bar, the ultimate bending strength of SFC specimens increase $12.6 \%$ compared to the NC specimens. Djamaluddin et al. (2014) to analyse the flexural behaviour of the beam with eliminated concrete parts below neutral axis then used truss system as external reinforced concrete beams.

Hollow reinforced concrete beam referred to in this study is which on the tension zone made hollow by using plastic bottles waste $60 \mathrm{~mm}$ diameter. There are some advantages using hollow in the tension section i.e., the structure will be lighter, the production of cement as the main material to make concrete will be reduced.

Corresponding Author: Syahrul Sariman, Department of Civil Engineering, Bosowa University, Makassar, Indonesia 
Table 1: Material properties

\begin{tabular}{llll}
\hline Concrete & & Steel reinforcement & \\
\hline Compr. strength & $27.09 \mathrm{MPa}$ & Compr. strength & $450 \mathrm{MPa}$ \\
Tensile strength & $3.9 \mathrm{MPa}$ & Tensile strength & $487 \mathrm{MPa}$ \\
Young modulus & $23 \mathrm{GPa}$ & Young modulus & $200 \mathrm{GPa}$ \\
\hline
\end{tabular}

Several studies have been carried out relating to hollow reinforced concrete beams including using PVC pipes such as those conducted by Joy and Rajeev (2014), Kumar and Joy (2015), Varghese et al. (2016), Dhinesh and Satheesh (2017) and Parthiban and Neelamegam (2017). Research by Sivaneshan and Harishankar (2017), utilizing recycled polythene balls, then put into a concrete mixture.

Another form of utilization of waste plastic products is to use PET plastic bottles by placing them as hollows formers as in the study Rahardyanto, using the plastic bottle waste to formed a hollow in RC beam. Mathew and Varghese (2016), conducted a hollow beam research using a test beam of size $20 \times 30 \times 200 \mathrm{~cm}$. Normal beam capacity (NOB0) compared to hollow beam with 10 PET bottles located on neutral lines (N10B0), hollow beam with 10 PET bottles located below the neutral line (N0B10) and hollow beam with 10 PET bottles on neutral lines and below the neutral line (N10B10). The test results show that the ultimate load capacity of all beam indicate similar. Sariman et al. compare the the hollow RC beams were $\mathrm{T}$ shaped with two conditions which were apparent $\mathrm{T}$ shaped beam and the neutral $\mathrm{T}$ shaped beam The result showed that there is not significantly different between two sample.

In this regard, a study was carried out on the flexural characteristics of reinforced concrete beams by using plastic bottles as hollows which were placed in a tension area. The volume of the hollows is varied in height and length.

The aim of this research was to analyze the ultimate moment capacity, the deflection-load relationship, the load and the steel strain relationship and the load and strain concrete relationship of the hollows beams. In addition, an analysis was also carried out to determine the boundaries of a hollows beam. concrete and steel reinforcement used in this study are presented in Table 1.

\section{MATERIALS AND METHODS}

Specimen and material properties: The dimensions of beams were $3300 \mathrm{~mm}$ length with $150 \times 350 \mathrm{~mm}$ cross section, respectively. The specimen used three of D16 steel bar as tensile reinforcement and two of $\varphi 8$ steel bar reinforcement at the compression side for assembly purpose only. For shear reinforcement used $\varphi 8-100 \mathrm{~mm}$ in support area and $\varphi 8-200 \mathrm{~mm}$ along the tested span. All beam had the same tensile reinforceme material properties of $h_{\text {rmax }}=h-80-c=350-80-90=180 \mathrm{~mm}$.

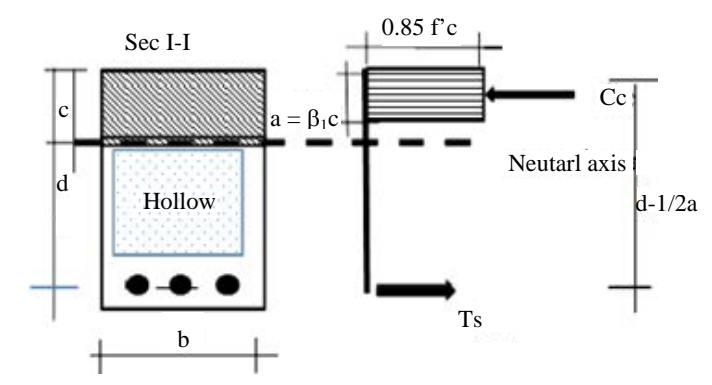

Fig. 2: Stress distribution of RC hollow beam

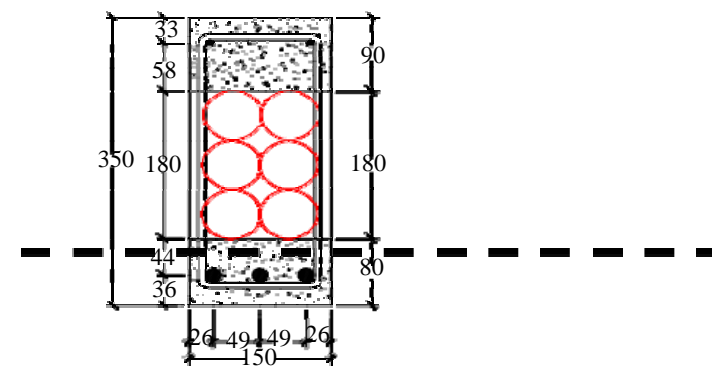

Fig. 3: Height of hollow max

Determine of the specimen dimension: The calculation of the RC beams under simply supported condition and bending moment as shown in Fig. 2:

$$
\begin{gathered}
\mathrm{Cc}=0.85 \mathrm{f} \text { 'c.a.b } \\
\text { Ts-As.fy } \\
\mathrm{Cc}=\mathrm{Ts} \\
\mathrm{a}=\frac{\text { As.fy }}{0.85 \mathrm{f} \text { 'c.b }}=\frac{602.97 * 481.78}{0.85 * 27.90 * 150}=76.53 \mathrm{~mm} \\
\mathrm{c}=\frac{\mathrm{a}}{\beta_{1}}=90.037 \mathrm{~mm}
\end{gathered}
$$

The height of hollow maximum (hmax): Sketch of the cross section specimen can be seen at Fig. 3. Variation of specimen, number and length of hollow can be seen at Table 2. The detail of the specimen can be seen at Fig. 4.

Figure 5 shows the casting of specimen. Concrete casting was started from the bottom of the specimen and was stopped until $70 \mathrm{~mm}$ height. After that, the plastic bottles were put on the concrete surface. The concrete casting was continued again which depends of the specimen variation. All specimen were cured for 28 days in the moisturing condition before testing. 
(a)
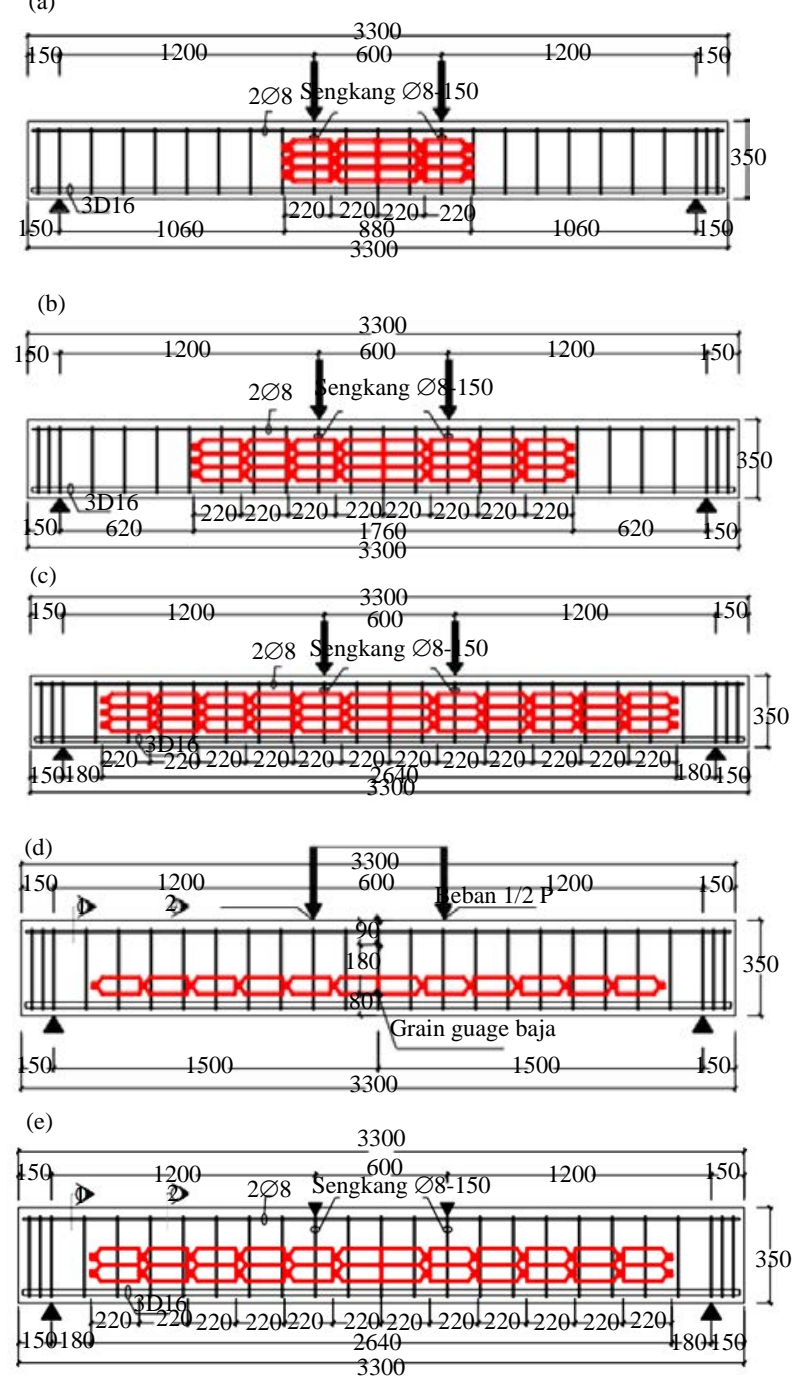

Fig. 4(a-e): Details of the specimen, (a) BR3A, (b) BR3B, (c) BR3C (d) BR1C and (e) BR2C

Table 2: Specimen variation

\begin{tabular}{lllcll}
\hline & No. of & \multicolumn{2}{l}{ Hollow length } & \multicolumn{2}{l}{ Hollow height } \\
Specimen & specimen & mm & No. of bottles & mm & No. of bottles \\
\hline BN & 3 & 0 & - & - & - \\
BR3A & 3 & 880 & 4 & 180 & 3 \\
BR3B & 3 & 1670 & 8 & 180 & 3 \\
BR3C & 3 & 2640 & 12 & 180 & 3 \\
BR1C & 3 & 2640 & 12 & 60 & 1 \\
BR2C & 3 & 2640 & 12 & 120 & 2 \\
\hline
\end{tabular}

Test set up: Several strain gauges were attached at the longitudinal reinforcement and shear reinforcement. Strain gauges also were attached at the concrete. Strain gauge was used to measure the strain of the steel and concrete. The location of attached strain gauges is shown in Fig. 6.

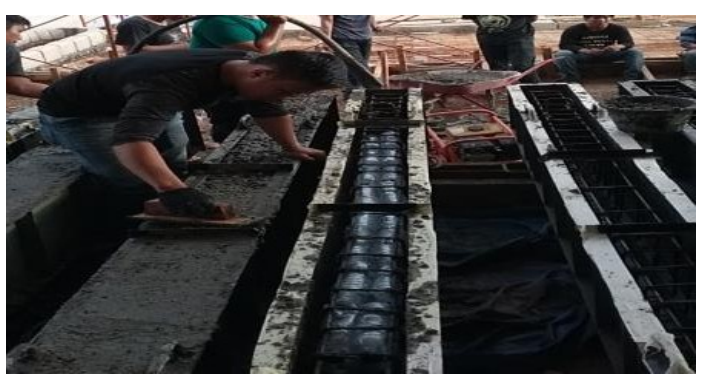

Fig. 5: Casting of specimen

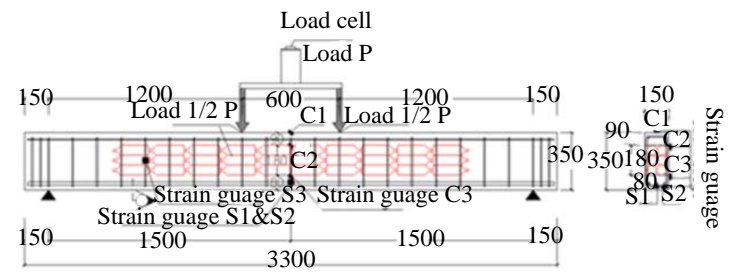

Fig. 6: Location of strain gauge

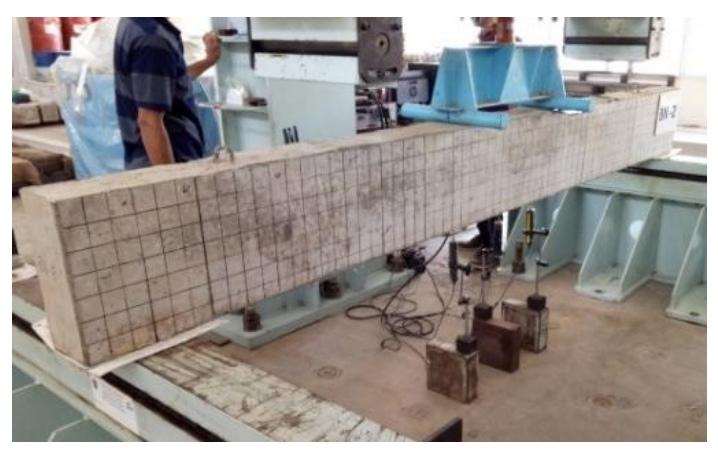

Fig. 7: Setup of specimen (BN)

Figure 7 shows the loading set up. All the beams were subjected to four point bending test using actuator with maximum load of $1500 \mathrm{kN}$. A load cell with $200 \mathrm{kN}$ capacity was used to measure the applied load.

\section{RESULTS AND DISCUSSION}

Type of failure: Based on the testing results, there are two types of failures which were reasonable failure and premature failure. Reasonable failure occurred if the theoretical load capacity of the RC hollow beam can be achieved or exceeded while premature failure of the RC hollow beam if the beam damage before reaching the theoretical load capacity. Type of beam which were reasonable failure and prematur failure as shown in Table 3.

Flexure charachteristic of the reasonable failure specimens will be compared among normal beams and hollow beams. In the analysis, the specimen divided into two variation which were length variation (BR3A, BR3B 
Table 3: Load capacity and type of failure

\begin{tabular}{llcl} 
& Max load $(\mathrm{kN})$ & & \\
Types of beam & - Theority & Experimental & Types of failure \\
\hline BN & 131.4 & 139.5 & Reasonable \\
BR3A & 131.8 & 139.5 & Reasonable \\
BR3B & 132.1 & 135.5 & Reasonable \\
BR3C & 132.2 & 136.8 & Reasonable \\
BR1C & 131.6 & 137.1 & Reasonable \\
BR2C & 131.9 & 99.9 & Premature \\
\hline
\end{tabular}

Table 4: Comparison moment capacity of the normal and hollow beam for the variation of the hollow length

\begin{tabular}{|c|c|c|c|c|c|c|}
\hline \multirow[b]{2}{*}{ Types of beams } & \multicolumn{3}{|c|}{ Momen (kNm) } & \multicolumn{3}{|c|}{ Moment to normal beam (\%) } \\
\hline & Mcr & My & $\mathrm{Mu}$ & Mcr & My & $\mathrm{Mu}$ \\
\hline $\mathrm{BN}$ & 11.1 & 77.1 & 85.1 & - & - & - \\
\hline BR3A & 10.9 & 77.4 & 84.9 & 97.6 & 98.9 & 99.72 \\
\hline BR3B & 10.6 & 75.8 & 82.0 & 96.8 & 98.6 & 97.23 \\
\hline BR3C & 10.5 & 76.1 & 83.0 & 96.3 & 96.4 & 98.12 \\
\hline
\end{tabular}

Table 5: Comparison moment capacity of the normal and hollow beam for the variation of the hollow height

\begin{tabular}{llllll}
\hline & \multicolumn{2}{c}{ Momen $(\mathrm{kN} \mathrm{m})$} & & \multicolumn{2}{c}{ Moment to normal beam (\%) } \\
Type of beams & Mcr & My & Mu & Mcr & My \\
\hline BN & 11.1 & 77.1 & 85.1 & - & - \\
BR1C & 10.8 & 76.9 & 83.5 & 97.9 & 98.7 \\
BR3C & 10.5 & 76.1 & 83.0 & 96.3 & 96.3 \\
\hline
\end{tabular}

Table 6: Bending moment capacity vs. weigth of the beam (length variation)

\begin{tabular}{lccc}
\hline Types of beam & Mu $(\mathrm{kNm})$ & $\mathrm{W}(\mathrm{kg})$ & $\mathrm{Mu} / \mathrm{W}$ \\
\hline BN & 83.1 & 419.3 & 0.203 \\
BR3A & 83.5 & 384.2 & 0.217 \\
BR3B & 83.5 & 384.2 & 0.217 \\
BR3C & 83.0 & 315.1 & 0.263 \\
\hline
\end{tabular}

and BR3C) and height variation (BR1C and BR3C). BR2C can not analyised, this specimen premature failure because the concrete covers too thin.

Comparison of moment capacity of normal beam and hollows beam: Bending moment capacity of the normal beam and hollows beam can be seen in Table 4 for the variation of hollow length and Table 5 for the variation of the hollow height.

Table 4 and 5 show that the moment capacity of all hollow beam was similar with the normal beam with the different was almost below 5\%. Previous researches were also shows similar results.

Ratio of the bending momen ultimate and weight of the specimen: Beam performance can be measured by comparing the ultimate moment with the weight of the beam $(\mathrm{Mu} / \mathrm{W})$. In the previous discussion it was known that the hollows in the beam did not significantly influence the beam's bending moment capacity. On the other hand, hollows of the beam influences the weight of the beam. Comparison of moment capacity and weight of specimens with variations in hollow length can be seen in Table 6 and Fig. 8.

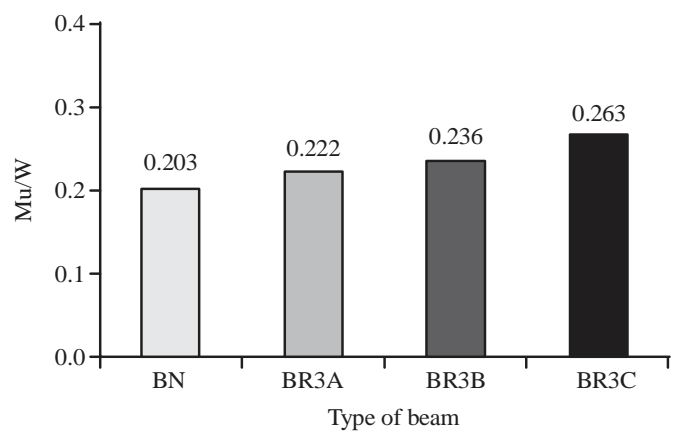

Fig. 8: Mu/W with variation in hollow length

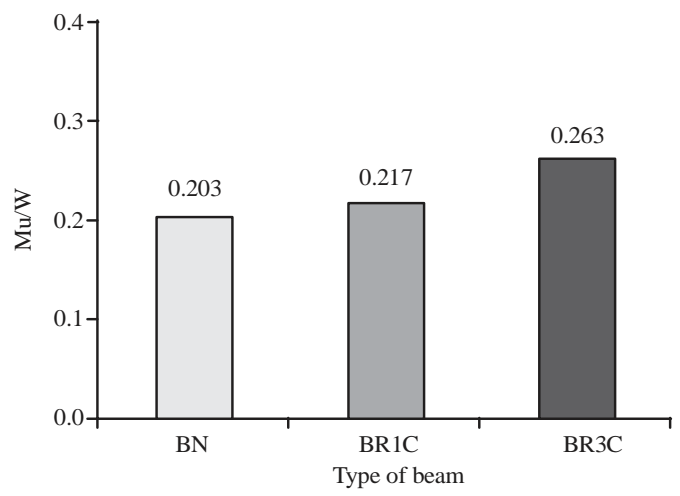

Fig. 9: $\mathrm{Mu} / \mathrm{W}$ with variation on hollow height

Comparison of moment capacity and weight of specimens with variations in hollow length can be seen in Table 7 and Fig. 9. 
J. Eng. Applied Sci., 15 (6): 1537-1543, 2020

Table 7: Bending moment capacity vs weigth of the beam (height variation)

\begin{tabular}{lllllll} 
Types of beam & Mu $(\mathrm{kNm})$ & $\mathrm{W}(\mathrm{Kg})$ & $\mathrm{Mu} / \mathrm{W}$ & & & \\
BN & 83.1 & 419.3 & 0.203 & & & \\
BR1C & 83.5 & 384.2 & 0.217 & $\Delta \mathrm{y}(\mathrm{mm})$ & $(\mathrm{kN})$ & $\Delta(\mathrm{mm})$ \\
Beam & Pcr $(\mathrm{kN})$ & $\Delta \mathrm{cr}(\mathrm{mm})$ & $\mathrm{Py}(\mathrm{kN})$ & 12.76 & 139.5 & 27.14 \\
\hline BN & 16.1 & 1.12 & 126.1 & 13.00 & 135.9 & 25.60 \\
BR1C & 15.9 & 1.10 & 126.1 & 14.06 & 136.8 & 25.70 \\
BR3C & 15.9 & 1.19 & 125.4 & & \\
\hline
\end{tabular}

Table 8: Load and deflection of hollow length variation

\begin{tabular}{|c|c|c|c|c|c|c|}
\hline \multirow[b]{2}{*}{ Types of beam } & \multicolumn{2}{|c|}{ Initial crack } & \multicolumn{2}{|l|}{ Yield } & \multicolumn{2}{|l|}{ Ulitimate } \\
\hline & Pcr $(\mathrm{kN})$ & $\Delta \mathrm{cr}(\mathrm{mm})$ & $\mathrm{Py}(\mathrm{kN})$ & $\Delta \mathrm{y}(\mathrm{mm})$ & $\mathrm{Pu}(\mathrm{kN})$ & $\Delta \mathrm{u}(\mathrm{mm})$ \\
\hline $\mathrm{BN}$ & 16.1 & 1.12 & 126.1 & 12.76 & 139.5 & 27.14 \\
\hline BR3A & 16.2 & 1.19 & 126.9 & 13.49 & 139.5 & 27.05 \\
\hline BR3B & 15.9 & 1.50 & 124.6 & 14.42 & 135.6 & 27.10 \\
\hline BR3C & 15.9 & 1.19 & 125.4 & 14.06 & 136.8 & 25.70 \\
\hline
\end{tabular}

Table 9: Load and deflection of hollow height variation

\begin{tabular}{|c|c|c|c|c|c|c|}
\hline \multirow[b]{2}{*}{ Types of beam } & \multicolumn{2}{|c|}{ Initial crack } & \multicolumn{2}{|l|}{ Yield } & \multicolumn{2}{|l|}{ Ulitimate } \\
\hline & $\operatorname{Pcr}(\mathrm{kN})$ & $\Delta \mathrm{cr}(\mathrm{mm})$ & $\mathrm{Py}(\mathrm{kN})$ & $\Delta \mathrm{y}(\mathrm{mm})$ & $\mathrm{Pu}(\mathrm{kN})$ & $\Delta \mathrm{u}(\mathrm{mm})$ \\
\hline $\mathrm{BN}$ & 16.1 & 1.12 & 126.1 & 12.76 & 139.5 & 27.14 \\
\hline BR1C & 15.9 & 1.10 & 126.1 & 13.00 & 135.9 & 25.60 \\
\hline BR3C & 15.9 & 1.19 & 125.4 & 14.06 & 136.8 & 25.70 \\
\hline
\end{tabular}

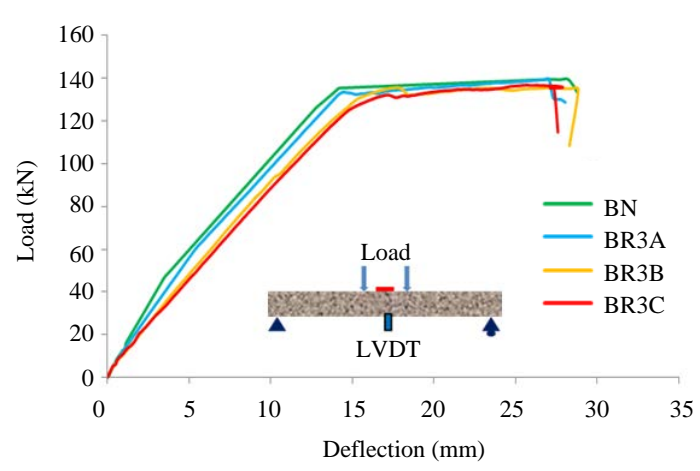

Fig. 10: Load deflection curve of the hollow length variation

In this research, in the hollow length variation, there was a reduction in weight of BR3A, BR3B and BR3C to $\mathrm{BN}$, respectively by $8.7,16.7$ and $26.6 \%$. In the hollow height variation, the reduction in weight of BR1C to BN is $8.1 \%$. This shows that the performance of hollow beams with variations in length and height of the hollows was good.

Load deflection relationship: Load deflection relationship at middle span for the $\mathrm{BN}$ and hollow beam of variation of hollow length (BN, BR3A, BR3B and BR3C) can be seen at Table 8 and Fig. 10. The load deflection ralationship of the hollow height variation can be seen at Table 9 and Fig. 11.

Generally, all the beams showed similar behaviour where the stiffness of load deflection curve reduced at the first cracking load (Pcr) and reduced again at the yielding load (Py). However, the stiffness of the beams was different which depends on the variation of each beam.

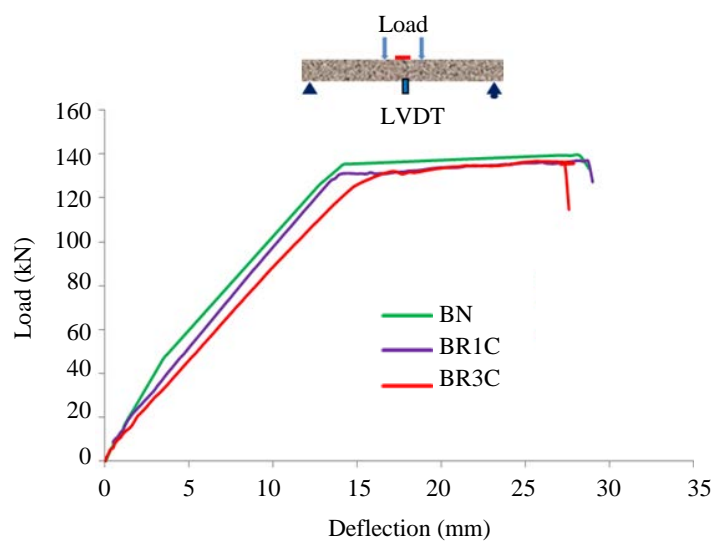

Fig. 11: Load deflection curve of the hollow height

Load strain of steel relationship: Load strain of reinforce steel relationship for the $\mathrm{BN}$ and hollow beam of variation of hollow length (BN, BR3A, BR3B and BR3C) and variation of hollow height (BN, BR1C and BR3C) can be seen at Fig. 12 and 13.

Figure 12 and 13 show all the specimen similar behaviour in load strain of steel relationship. The curve shown, strain of the steel had exceeded the yield point. This indicate there is no influence of the hollow to the steel reinforcement strain.

Previous researches were also shows similar results. Research by Joy et al. which using by PVC pipe and Mathew and Varghese (2016) using a plastic bottle waste indicate similar result.

Load strain of concrete relationship: Load strain of concrete in top of beam relationship for the $\mathrm{BN}$ and 


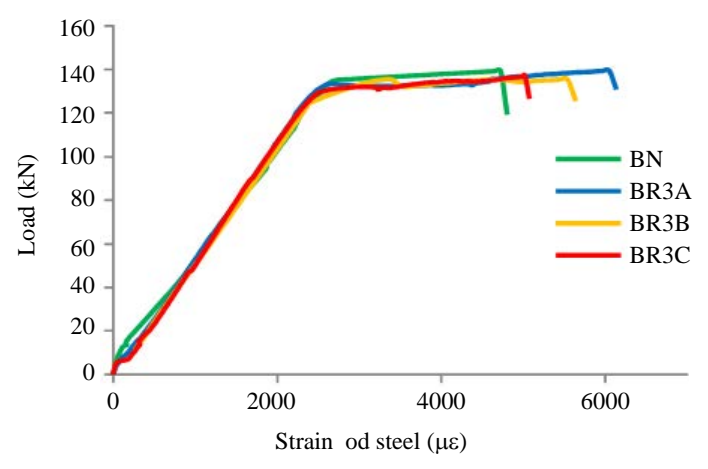

Fig. 12: Load strain of steel curve of the hollow length variation

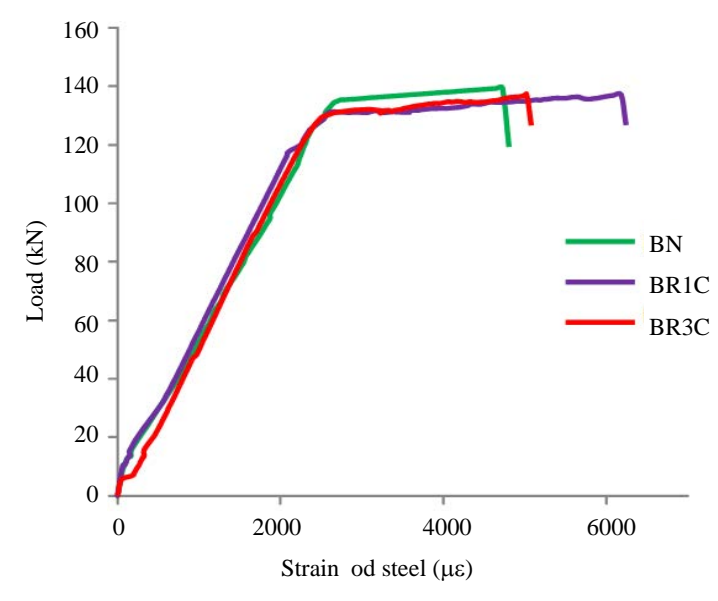

Fig. 13: Load strain of steel curve of the hollow height variation

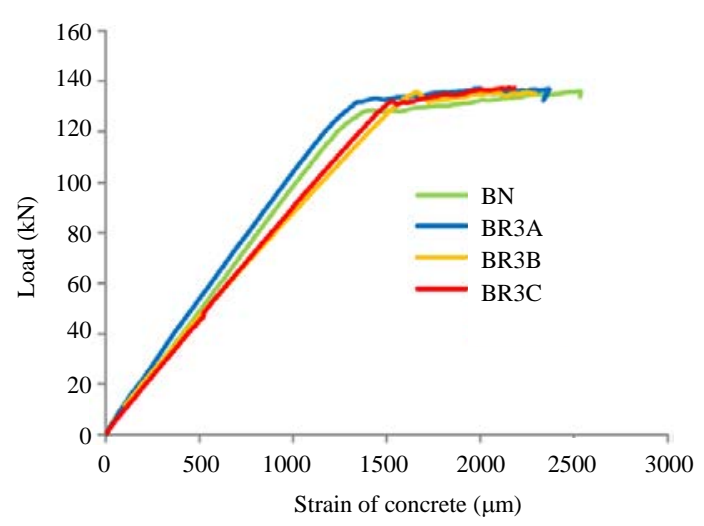

Fig. 14: Load strain of concrete with hollow length variation

hollow beam of variation of Hollow length (BN, BR3A, $\mathrm{BR} 3 \mathrm{~B}$ and $\mathrm{BR} 3 \mathrm{C})$ and variation of hollow height (BN, BR1C and BR3C) can be seen at Fig. 14 and 15.

Figure 14 and 15 show all the specimen similar behaviour in load strain of concrete. All of the specimen show the strain of concrete can not reached $3000 \mu \mathrm{m}$,

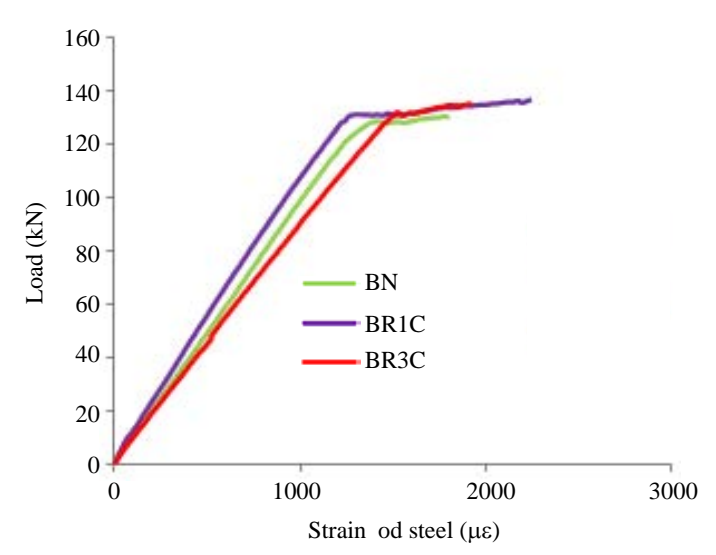

Fig. 15: Load strain of concrete curve of the hollow height variation

means the concrete hadn't reached the limit strain. This indicate there is no influence of the hollow to the concrete strain.

\section{CONCLUSION}

Based on experimental results, it can be concluded that: the beam with hollow length variation, obtained ultimate moment of BR3A:84.86, BR3B:82.03 and BR3C:83.01 kNm, in significant different to BN: $85.10 \mathrm{kNm}$. More over curve of load defelection relationship, load strain of steel relationship and load strain of concrete relationship was similar. The beam with hollow height variatioan, obtained ultimate moment of the BR1C:83.52 $\mathrm{kNm}$ or $98.31 \%$ to ultimate moment of $\mathrm{BN}: 85.10 \mathrm{kN}$. Curve of load defelection relationship, load strain of steel relationship and load strain of concrete relationship was similar too. Ratio ultimate moment and weight of the specimen showed that the hollow beams performance of hollow beams with variations in length and height of the hollows was good.

\section{ACKNOWLEDGEMENT}

The researcher would like to thank rector and civitas academica Bosowa University and The Head Staff of the Structure and Strengthening Research Laboratory of Hasanuddin University, for their kind support to this research.

\section{REFERENCES}

Dhinesh, N.P. and V.S. Satheesh, 2017. Flexural behaviour of hollow square beam. Int. J. Sci. Eng. Applied Sci. (IJSEAS.), 3: 236-242.

Djamaluddin, R., Y. Bachtiar, R. Irmawati, A.M. Akkas and R.U. Latief, 2014. Effect of the truss system to the flexural behavior of the external reinforced concrete beams. Int. J. Civil Archit. Struct. Constr. Eng., 8: 938-942. 
Irmawaty, R., R. Djamaluddin and W.O. Malim, 2016. Flexural behavior of Styrofoam-filled concrete. Int. J. Eng. Sci. Appl., Vol. 3, No. 1.

Joy, J. and R. Rajeev, 2014. Effect of reinforced concrete beam with hollow neutral axis. IJSRD-Int. J. Sci. Res. Dev., Vol. 2, No. 10.

Kumar, A.S. and A. Joy, 2015. Experimental investigation on partial replacement of concrete below neutral axis of beam. Int. J. Sci. Res., 4: 1670-1674.

Mathew, I. and S.M. Varghese, 2016. Experimental study on partial replacement of concrete in and below neutral axis of beam. Int. J. Innovative Res. Technol., 3: 188-192.
Parthiban, N. and M. Neelamegam, 2017. Flexural behavior of reinforced concrete beam with hollow core in shear section. Int. Res. J. Eng. Technol. (IRJET.), 4: 2263-2274.

Sivaneshan, P. and S. Harishankar, 2017. Experimental study on voided reinforced concrete beams with polythene balls. IOP Conf. Ser. Earth Environ. Sci., Vol. 80, No. 1.

Varghese, A. and M.J. Basil, 2016. Experimental and numerical studies on reinforced concrete hollowcore sandwich beams. Int. J. Innovative Res. Sci. Eng. Technol., 5: 14730-14737.

Varghese, N. and A. Joy, 2016. Flexural behaviour of reinforced concrete beam with hollow core at various depth. Int. J. Sci. Res. (IJSR.), 5: 741-746. 